\title{
The Treatment of Encyclopedic Information in Duramazwi reMimhanzi
}

Gift Mheta, Department of Linguistics, University of the Western Cape, Bellville, Republic of South Africa (2971565@uwc.ac.)

\begin{abstract}
This article presents the problems and challenges of dealing with encyclopedic information in Shona lexicography. According to Zgusta (1971: 198), encyclopedic dictionaries are primarily concerned with the denotata of the lexical units. They give information about the extralinguistic world, physical or non-physical. In other words, encyclopedic dictionaries contain extensive information on lexical entries. The article focuses on how such encyclopedic information is collected, selected, entered and treated. Emphasis is on identifying the problems and challenges experienced by lexicographers at the four main stages of dictionary making. It also presents solutions to the encountered difficulties. It brings out discernible patterns in the treatment of encyclopedic information. The analysis, from the collection stage up to the treatment stage, is done with reference to the relatively long history of compiling linguistic dictionaries in Shona.
\end{abstract}

Keywords: ENCYCLOPEDIA, COLLECTION, TREATMENT, ENTRY, ETYMOLOGY, ILLUSTRATION, LEXICOGRAPHY, LINGUISTIC DICTIONARY, MUSIC, SELECTION

Opsomming: Die behandeling van ensiklopediese inligting in die samestelling van Duramazwi reMimhanzi. Hierdie artikel behandel die probleme en uitdagings by die aanbieding van ensiklopediese inligting in Sjonaleksikografie. Volgens Zgusta (1971: 198 ) is ensiklopediese woordeboeke primêr gemoeid met die denotata van die leksikale eenhede. Hulle verskaf inligting oor die ekstralinguistiese wêreld, fisies en niefisies. Met ander woorde, ensiklopediese woordeboeke bevat uitvoerige inligting oor leksikale inskrywings. Die artikel fokus op hoe sulke ensiklopediese inligting versamel, gekeur, aangebied en behandel word. Klem is op die identifisering van probleme en uitdagings wat deur leksikograwe ondervind word by die vier hoofstadiums van woordeboekmaak. Dit bied ook oplossings vir die teëgekome probleme. Dit bring onderskeibare patrone in die behandeling van ensiklopediese inligting na vore. Die ontleding, van die versamelingstadium tot by die behandelingstadium, word gedoen met verwysing na die relatiewe lang geskiedenis van die samestelling van linguistiese woordeboeke in Sjona.

Sleutelwoorde: ENSIKLOPEDIE, VERSAMELING, BEHANDELING, INSKRYWING, ETIMOLOGIE, ILLUSTRASIE, LEKSIKOGRAFIE, LINGUISTIESE WOORDEBOEK, MUSIEK, KEUSE

\section{Introduction}

After the publication of Duramazwi reChiShona (1996) and Duramazwi Guru reChiShona (2001), there has been a paradigm shift in Shona lexicography, from 
the production of general linguistic dictionaries to the compilation of specialized dictionaries as evidenced by the publication of the first two of these, Duramazwi reUrapi NeUtano (2004) and Duramazwi reMimhanzi (2005).

This article highlights the experiences and challenges faced by the African Languages Research Institute (ALRI) in the compilation of an encyclopedic music dictionary, Duramazwi reMimhanzi (henceforth the DRM). The article is based on experiences and observations as editor-in-chief of the DRM. The dictionary, published in 2005, is the first of its kind in the lexicographic history of Zimbabwe. The DRM is trilingual, presenting three languages, namely Shona, Ndebele and English, the official languages in Zimbabwe. However, the dictionary has one alphabetizing language, i.e. Shona, spoken by 75 percent of the country's population of 11.6 million people. In this dictionary, Shona headwords are followed by equivalent terms in Ndebele and English and then by definitions, all in the Shona language. At the end of the Aa-Zz section of the dictionary, there is a section with illustrations followed by two indices, the one comprising Ndebele and English equivalent terms and the other made up of Ndebele headwords and Shona glosses. The dictionary is targeted at tertiary institutions and some secondary schools offering music as a course or subject.

\section{Collection Stage}

Challenges of compiling the DRM were encountered at the initial collection stage. The main problem was how to collect terms for such a specialized dictionary when there were no other Shona musical terms dictionaries. The DRM editorial team ended up relying on general linguistic dictionaries such as Duramazwi reChiShona and Duramazwi Guru reChiShona. However, the editorial team only managed to collect about 700 Shona musical terms. With a target of between 1000 and 1500 musical terms, ways of reaching the set target had to be explored. The DRM editorial team resolved to work with different experts in the music field who included music lecturers and teachers, musicians and performers. Despite contributing greatly to the compilation of the DRM, the reference working groups (RWGs) presented a number of problems to the lexicographic team. The main problem was that the groups had to consist of music lecturers and teachers together with linguists from all the provinces in Zimbabwe so that whatever the editorial team together with the RWGs agreed upon, especially newly created terms, would be accepted nationwide.

Assembling RWGs required an initial survey aimed at identifying personnel with relevant credentials throughout Zimbabwe. This survey was carried out during 2002, establishing contacts nationwide. It required much travelling which had serious financial implications. A substantial amount was required for planning and carrying out the trips in various parts of the country. At least three experts were identified in every province. The RWGs worked closely with the DRM team from the collection right up to the definition stage. However, the other problem was that the RWGs were not as big as desired since 
members of these groups had to be paid for their professional services.

Notwithstanding the challenges encountered in working with these experts, the team managed to collect and define the 1200 musical terms found in the DRM today.

\section{Selection Stage}

Selection of indigenous musical terms was not a problem because there are not so many of them. As already mentioned above, musical terms collected from Shona dictionaries constituted less than half of the set target. Selection problems only appeared when dealing with Western musical terms to be included in the dictionary. The problem lay in choosing from the abundance of Western musical terms. The New Grove Dictionary of Music and Musicians, for instance, consists of twenty volumes, each having approximately 900 pages. With the upper limit of the target for music headwords fixed at 1500 , the selection process had inevitably to be strict. The team ended up formulating stringent selection guide-lines that would yield the most salient music headwords from Western music literature. All elements of music, for instance, had to be incorporated into the dictionary since they constitute the core of the music discipline. In this manner terms such as beat, harmony, melody, pitch, pulse, tempo and rhythm were prioritized over other musical terms dealing with musical concepts alien to Zimbabwean music culture.

\section{Entry Stage}

With the experience of compiling linguistic dictionaries, the editorial team at ALRI was faced with the challenge of selecting what to enter into the database. It agreed to enter no grammatical information other than tone and etymology, which add to encyclopedic information. An encyclopedic dictionary offers a more complete description of entries than a linguistic dictionary. In order to have comprehensive information about entries, the editorial team had to enter etymological information for newly created musical terms especially those concepts borrowed from Western music. The histories of the newly adopted terms were included to complement the treatments. The target users are likely to be informed of the meanings of new terms even before reading the treatments. An example demonstrating how etymological information is included is the following (Mheta 2005: 7-8):

bhesi [bhasi] KD ibhesi (ND) bass (EN). <ChiRatini bassus 'kudzama/kudzika'>. Bhesi izwi gobvu rakadzikira repasi pamazwi mana anowanzoshandiswa pakuimba. Izwi rerudzi urwu rinowanzoshandiswa pakuimba nevanhurume asi kune vamwe vanhukadzi vanorikwanisa. Kune zviridzwa zvakasiyanasiyana zvinobudisa bhesi. 
(bhesi [bhasi] HL ibhesi (ND) bass (EN). <Latin bassus 'deep'>. Bass is a voice that is deep. It is the lowest when compared to the other three voice registers that are mainly used when singing. Bass is usually sung by men, but there are some women who can also sing it. There are numerous musical instruments that also produce bass.)

\section{Treatment Stage}

Defining of musical terms presented a number of challenges. The most difficult task was how to construct a framework for treating terms in a manner that would yield definitions with more encyclopedic information than those found in linguistic dictionaries. Since the dictionary is encyclopedic in nature, the editorial team had to frame treatment guidelines ensuring the inclusion of most of the encyclopedic information. Treatment guidelines for all major entries or concept categories such as ceremonies, costumes, dances, instruments, performers and songs were framed for use in the treatment of all headwords in the DRM. For instance:

Treatment of ceremonies had to consider:

(a) whether the ceremony is traditional or modern as well as where it (especially the traditional) is performed,

(b) the purpose or context of the ceremony,

(c) the participants involved,

(d) the costumes worn, and

(e) the type of songs/instruments played.

Treatment of costumes had to consider:

(a) whether the costume is traditional or modern,

(b) the type of material used in making the costume,

(c) the people wearing the costume and how it is worn,

(d) the importance/significance of the costume, and

(e) the ceremonies and geographical regions in which the costume is worn.

Treatment of dances had to consider:

(a) whether the dance is traditional or modern,

(b) the origin and region where it (especially the traditional) is found,

(c) the performer(s) of the dance as well as the context of the dance and time when it is performed,

(d) the costumes worn, equipment used or instruments played, and

(e) the type of music involved.

Treatment of instruments had to consider:

(a) the type of material used in the making of the instrument, e.g. reed, wood, clay, metal or fibre glass, 
(b) the parts which constitute the instrument,

(c) the size of the instrument, e.g. small, medium, large,

(d) the way of playing the instrument, e.g. plucked, shaken, beaten, stamped, scraped and blown,

(e) the character of the sound produced by the instrument, e.g. sharp, pitched, heavy, light, piercing, etc.,

(f) the classification system, i.e. Nketia's or Mararire's,

(g) the period to which the instrument belongs, i.e. whether it is modern or traditional,

(h) the source of origin of the instrument, and

(i) the player of the instrument, the context in which it is played, and also its music and non-music functions.

With clearly spelt out definition formats it became easy for the editorial team to draft exhaustive treatments contrasting with the concise ones found in linguistic dictionaries. A comparison of the two treatments, one from the DRM and the other from Duramazwi Guru reChiShona clearly illustrates this point.

Treatment from the DRM (Mheta 2005: 87):

nyungwenyungwe [nyunganyunga] KDKD inyungwenyungwe (ND) mbira (EN). Nyungwenyungwe nderumwe rudzi rwembira rune makiyi anokwana gumi neshanu. Inoridzwa kazhinji muzvikoro nemakoreji anodzidzisa nezvemimhanzi. Mukuiridza muridzi anoshandisa gamburabota kuridza makiyi epasi okurudyi kwake uye gamburabota rekuruboshwe kuridza makiyi epasi okuruboshwe kwake. Anoshandisawo munongedzo wekurudyi kuridza makiyi epamusoro ese. Imbira inokwanisa kuridzwa chero naani zvake nguva ipi zvayo. Yakabva kudunhu reNyungwe kuMozambiki naJeke Tapera uyo akauya nayo muZimbabwe kuma1960 akatanga kudzidzisa maridzirwe ayo paKwanongoma College of Music yava kunzi United College of Education kuBulawayo. Inowanikwawo zvakare kuAmerika uko yakaendeswa nemushakabvu Dumisani Abraham Maraire aiiridza nekuidzidzisa ikoko. FAN karimba.

nyungwenyungwe [nyunganyunga] HLHL inyungwenyungwe (ND) mbira (EN). Nyungwenyungwe is a type of mbira that has 15 keys. It is usually played in schools and tertiary institutions that teach music. When playing it, the instrumentalist uses the left thumb to pluck the bottom placed keys on his/her right side and uses the right index finger to pluck the upper keys. It is a type of mbira that can be played by anyone at any given time. The instrument originated from the Nyungwe District in Mozambique where it was discovered by Jeke Tapera who brought it to Zimbabwe in the 1960s and started teaching students at Kwanongoma College of Music, now known as the United College of Education, in Bulawayo how to play it. Nyungwenyungwe is also found in the United States where it was introduced at various universities by the late musician and ethnomusicologist Dumisani Abraham Maraire. SYN karimba. 
Treatment from Duramazwi Guru reChiShona (Chimhundu 2001: 772):

nyunganyunga KDKD z 9>10. Nyunganyunga nderumwe rudzi rwembira rwunoridzwa. FAN karimba 12.

(nyunganyunga HLHL n 9>10 Nyunganyunga is a type of mbira that is played. SYN karimba 12.)

The abundance of information on musical terms shows that the DRM editorial team successfully framed treatment guidelines which have helped in the tapping of as much encyclopedic information as possible. Having dealt with the problem of how to define terms in an encyclopedic dictionary, the editorial team was left with the challenge of how to complement the definitions in the dictionary.

\section{Illustrations}

One of the decisions made by the DRM editorial team was to include illustrations between the dictionary and indices sections. The illustrations mainly depict musical instruments, costumes and music notational symbols. It was, however, difficult to make a choice on the type of illustrations to be included. Photographs would have been preferred since they are user-friendly, fully capturing most features of the items to be illustrated. They enhance a dictionary. However, good quality paper which is essential for the inclusion of photographs is very costly. This is the main reason why the DRM team opted for line drawings. The only problem is that line drawings are not as easily accessible as photographs. They require users to have prior knowledge of the concepts being illustrated. Research shows that they can easily be misunderstood by users unfamiliar with certain drawing techniques and conventions such as cross-sections.

\section{Conclusion}

Compiling encyclopedic dictionaries is not an easy task as demonstrated by the numerous challenges met by the ALRI lexicographic team in the compilation of the DRM. Such challenges were only solved by close co-operation with experts in the music field. Working closely with experts in specialized fields is the key to success in the production of encyclopedic dictionaries.

\section{Bibliography}

Chimhundu, H. 1996. Duramazwi reChiShona. Harare: College Press.

Chimhundu, H. 2001. Duramazwi Guru reChiShona. Harare: College Press.

Mheta, G. 2005. Duramazwi reMimhanzi. Gweru: Mambo Press.

Mpofu, N. 2004. Duramazwi reUrapi neUtano. Gweru: Mambo Press.

Zgusta, L. 1971. Manual of Lexicography. Prague: Academia / The Hague/Paris: Mouton. 